\title{
THINK PIECES IN ANALYTICS
}

Experimenting with the many potentials of anthropological analysis-that shifting interface between the empirical and the conceptual, the space and perhaps the time between ethnography and theory-is at the heart of our journal's intellectual mission. Our aim is to publish articles that display a spirit of analytical exploration by dealing in fresh ways with their empirical materials and showing in the action of their analytical treatment new paths for anthropological thinking to pursue.

Alongside full-length research articles, in this issue we inaugurate Think Pieces in Analytics, a forum devoted to slightly shorter and more speculative texts, in which particular aspects of the scope, process, or aims of anthropological analysis are explored for their own sake. Mirroring the ambiguous and shifting character of both the concept and the practice of analysis, we give free rein to contributors to broach matters of methodology, theoretical approach, research ethics and politics, interdisciplinary interface, and institutional infrastructure, as long as their bearing on questions of analytical practice in anthropology is identified.

Our two inaugural think pieces in the present issue of the journal illustrate this freedom of scope. Yang Liu and Thomas Malaby's article, "Speculating (on the Digital and the Monetary)," takes stock of the development of digital anthropology as, by now, a well-established subfield within the discipline, asking, effectively, what it is to analyze the digital anthropologically. In doing so, they pursue an analogy, sometimes made in the literature, between digital technology and money. Both, they suggest, conjoin, on the one hand, a tendency toward abstraction and, on the other, the diversely contingent social processes in which they operate. How far can this analogy, then, shed light in particular on the way in which the contingency of the social process of digital practices features in anthropologists' analyses? Daniel Miller, one of the pioneers in the field with whose work Liu and Malaby engage in detail, offers his critical response to their proposals.

If Liu and Malaby's think piece pertains to the analytical techniques practiced by anthropologists at their desks, the article by Sevasti-Melissa Nolas and Christos Varvantakis, "Field Notes for Amateurs," concerns the practice of 
ethnographic fieldwork itself. Drawing on their experience conducting research for a large, ERC-funded project on the connections between childhood and public life in urban environments, the authors mount a spirited defense of 'becoming childlike' as a stance for the research process itself. Following desire lines playfully, they suggest, may be a prime antidote to the rectilinear conventions of 'professionalization' in the contemporary research industry. This is an argument with broader political implications for the conduct of empirically driven analysis in the era of what the authors describe as a 'neo-liberal' regime of accountability in academic labor. How to counter money's propensity to abstract itself, albeit in two rather different senses, may be the common denominator of this issue's two think pieces in analytics.

- The Editor

Martin Holbraad teaches social anthropology at University College London. He is the author of Truth in Motion: The Recursive Anthropology of Cuban Divination (2012), co-author of The Ontological Turn: An Anthropological Exposition (2016, with Morten Axel Pedersen), and co-editor of Thinking Through Things: Theorising Artefacts Ethnographically (2007, with Amiria Henare and Sari Wastell) and Framing Cosmologies: The Anthropology of Worlds (2014, with Allen Abramson). At present, he is directing a five-year research project on the anthropology of revolutionary politics. He became editor of Social Analysis in 2016. E-mail: sa@berghahnjournals.com 